University of Nebraska - Lincoln

DigitalCommons@University of Nebraska - Lincoln

To Improve the Academy

Professional and Organizational Development Network in Higher Education

1996

Section II: Faculty Development

Follow this and additional works at: https://digitalcommons.unl.edu/podimproveacad

Part of the Higher Education Administration Commons

"Section II: Faculty Development" (1996). To Improve the Academy. 365.

https://digitalcommons.unl.edu/podimproveacad/365

This Article is brought to you for free and open access by the Professional and Organizational Development Network in Higher Education at DigitalCommons@University of Nebraska - Lincoln. It has been accepted for inclusion in To Improve the Academy by an authorized administrator of DigitalCommons@University of Nebraska - Lincoln. 


\section{Section II:}

\section{Faculty Development}

The five articles focused on faculty development in this issue use assessment and surveys to bring us information on the state of our faculty. Travis, Hursh, Lankewicz, and Tang review a number of institutional approaches to gathering data from faculty. Chism and Szabó report on their assessment of what categories of faculty use faculty development services. Smith and Geis explore approaches to faculty development and their implications for serving faculty as clients. Lunde and Wilhite present their findings about sources of ideas, teaching strategies, and persistence in changing teaching from a survey of faculty who have received teaching awards, non-award winners, and new faculty. And Menges reports on faculty experiences during their first three years and how faculty development programs can help ease their transition to their new jobs. 